\title{
Excessive anterior cervical muscle tone affects hyoid bone kinetics during swallowing in healthy individuals [Corrigendum]
}

Yamazaki Y, Tohara H, Hara K, Nakane A, Wakasugi Y, Yamaguchi K, Minakuchi S. Clin Interv Aging. 2017;12: 1903-1910.

Page 1903, the title, "Excessive anterior cervical muscle tone affects hyoid bone kinetics during swallowing in healthy individuals" should read "Excessive anterior cervical muscle tone affects hyoid bone kinetics during swallowing in adults".

Page 1903, Abstract, Purpose, line 3, "healthy individuals" should read "adults".

Page 1903, Abstract, Subjects and methods, "28 healthy adults (12 men, 16 women; mean age, 39.75 19.50 years) without any history or present complaints of swallowing disorders" should read " 28 adults ( 12 men, 16 women; mean age, $39.75 \pm 9.50$ years) who were suspected to have some symptom of swallowing disorders but did not have swallowing dysfunctional from the result of videofluorography".

Page 1904, right column, line 10, "healthy individuals" should read "adults".

Page 1904, Methods, Study participants, "The present study evaluated 28 healthy adults (12 men, 16 women; mean age,
$39.75 \pm 9.50$ years) without any history or present complaints of swallowing disorders" should read "The present study evaluated 28 adults (12 men, 16 women; mean age, $39.75 \pm 9.50$ years) who were suspected to have some symptom of swallowing disorders but did not have swallowing dysfunctional from the result of videofluorography".

Page 1908, Excessive anterior cervical muscle tone effect on the maximum elevated position of hyoid bone, line 7 , "In other words, in healthy individuals" should read "In other words, in adults".

Page 1909, left column, line 6, "participants of this study were healthy adults" should read "participants of this study were adults without obvious dysphagia".

Page 1909, Limitations, line 11, “Third, as our experiments were conducted in healthy adults" should read "Third, as our experiments were conducted in adults".

Page 1909, Conclusion, line 3, "we used VF to examine healthy adults" should read "we used VF to examine adults without obvious dysphagia".
Clinical Interventions in Aging

\section{Publish your work in this journal}

Clinical Interventions in Aging is an international, peer-reviewed journal focusing on evidence-based reports on the value or lack thereof of treatments intended to prevent or delay the onset of maladaptive correlates of aging in human beings. This journal is indexed on PubMed Central, MedLine,

\section{Dovepress}

CAS, Scopus and the Elsevier Bibliographic databases. The manuscript management system is completely online and includes a very quick and fair peer-review system, which is all easy to use. Visit http://www.dovepress. com/testimonials.php to read real quotes from published authors. 